\title{
ISOELECTRIC FOCUSING STUDIES IN BRAZILIAN INDIANS --UNCOVERING VARIATION OF ORM, AHSG AND IF_-
}

\author{
Francisco M. Salzano, ${ }^{1}$ Kazuo Umetsu, ${ }^{2, *}$ Isao Yuasa, ${ }^{3}$ \\ Francis L. BLACK, ${ }^{4}$ and Tsuneo SUZUKI ${ }^{2}$ \\ ${ }^{1}$ Departamento de Genética, Instituto de Biociências, Universidade Federal do Rio Grande do Sul, \\ Caixa Postal 1953, 90001 Porto Alegre, RS, Brazil \\ ${ }^{2}$ Department of Forensic Medicine, Yamagata University School of Medicine, \\ Yamagata 990-23, Japan \\ ${ }^{3}$ Department of Legal Medicine, Tottori University School of Medicine, \\ Yonago 683, Japan \\ ${ }^{4}$ Department of Epidemiology and Public Health, Yale University School of Medicine, \\ 60 College Street, New Haven, CT 06510, USA
}

\begin{abstract}
Summary Allele frequencies for the orosomucoid I (ORM1), orosomucoid 2 (ORM2), alpha-2-HS-glycoprotein (AHSG) and complement component I (IF) loci were studied in 393 individuals of three Brazilian Indian tribes. In the ORM1 locus only two alleles were observed among the Urubu-Kaapor, while five were found among the Pacaás Novos. The frequency of $O R M I^{*} 1$ was similar in these two tribes $(0.734$ and 0.715 , respectively) but departed more markedly among the Parakanã $(0.870)$. Variation for ORM2 locus was found among the Pacaás Novos only, with $O R M 2^{*} 3$ being observed in just three individuals. A new variant $\left(A H S G^{*} P N\right)$ was found in the AHSG system. Frequency for $A H S G^{*} I$ was unexpectedly low in the three tribes, especially, among the Pacaás Novos, where the prevalence $(0.145)$ is the lowest considering other data reported thus far. For IF locus, variability was also restricted to only one trible (Urubu-Kaapor) and attributed to a new polymorphic allele, $I F^{*} A 3$.
\end{abstract}

Key Words polymorphism, Brazilian Indians, ORM1 and ORM2, AHSG, IF

\section{INTRODUCTION}

Technological improvements are making possible the discovery of enormous amounts of variability in the gene pool of human and other species. The necessary knowledge about the variations in different populations of the world, however, is lagging behind. This is due to several causes, two of the most important being

Received October 8, 1990; Accepted October 29, 1990.

* To whom correspondence should be addressed. 
the present emphasis on linkage studies involving mainly pathological traits, and the difficulty of establishing in a given center all the techniques necessary for these investigations. It is important to change this trend because to really understand the mechanisms involved in the causes of these vatiation markers influencing processes at different levels of the biological spectrum (DNA, proteins of different types) should be studied. The implication is that the information available for traditional systems should be complemented with that involving new ones, as additional research tools develop.

The present report presents results on the orosomucoid 1 (ORM1), orosomucoid 2 (ORM2), alpha-2-HS-glycoprotein (AHSG) and complement component I (factor I, IF) loci for three Brazilian Indian tribes, already studied for around 30 other systems (Hamel et al., 1984; Salzano et al., 1985; Black et al., 1988). The information available for ORM1 and ORM2 is thus extended, and the first results for AHSG and IF in unmixed Amerindians are given, with the concomitant discovery of new variants. After integrating these old and new data some features of the world distribution of these markers will be discussed.

\section{MATERIALS AND METHODS}

The groups studied can be characterized as follows (see Fig. 1 for their geographical location):

(1) Urubu-Kaapor: they speak a Tupi language and are settled on a reservation located between $46^{\circ}$ to $47^{\circ} \mathrm{W}$ and $2^{\circ}$ to $3^{\circ} \mathrm{S}$ in the Brazilian State of Maranhão. Total population is 710 persons. Peaceful contacts with non-Indians were started in 1928, but despite this relatively long interaction they still keep much of their culture (Samain, 1984/85; Ricardo, 1986). The samples were collected in seven villages scattered along the reservation, but since the number obtained in each was small they were pooled for this analysis. Previous genetic studies among them were reported by Black et al. (1988).

(2) Parakanã : they also speak a Tupi language. The present sample was collected at the village Bom Jardim $\left(5^{\circ} 55^{\prime} \mathrm{S}, 52^{\circ} 42^{\prime} \mathrm{W}\right)$, which had a total population, in 1984, of 133. Other members of this tribe live in two other villages with 139 and 72 inhabitants, respectively. First contacts with non-Indians started in the 1970 s only. Other genetic and cultural information about them can be found in Black et al. $(1980,1988)$.

(3) Pacaás Novos: their language can be classified in the Chapacura stock. The approximately 1,000 persons live in several communities in the Brazilian State of Rondonia, near the Bolivian border. The samples were obtained at the villages of Tanajura $\left(11^{\circ} 5^{\prime} \mathrm{S}, 65^{\circ} 10^{\prime} \mathrm{W}\right)$, at the margins of the Pacaás river, and Santo André, located about $40 \mathrm{~km}$ up river. Contacts of a more permanent nature with nonIndians started in 1961. Further details about the demography, culture and genetics of these Indians can be obtained in Hamel et al. (1984) and Salzano et al. 


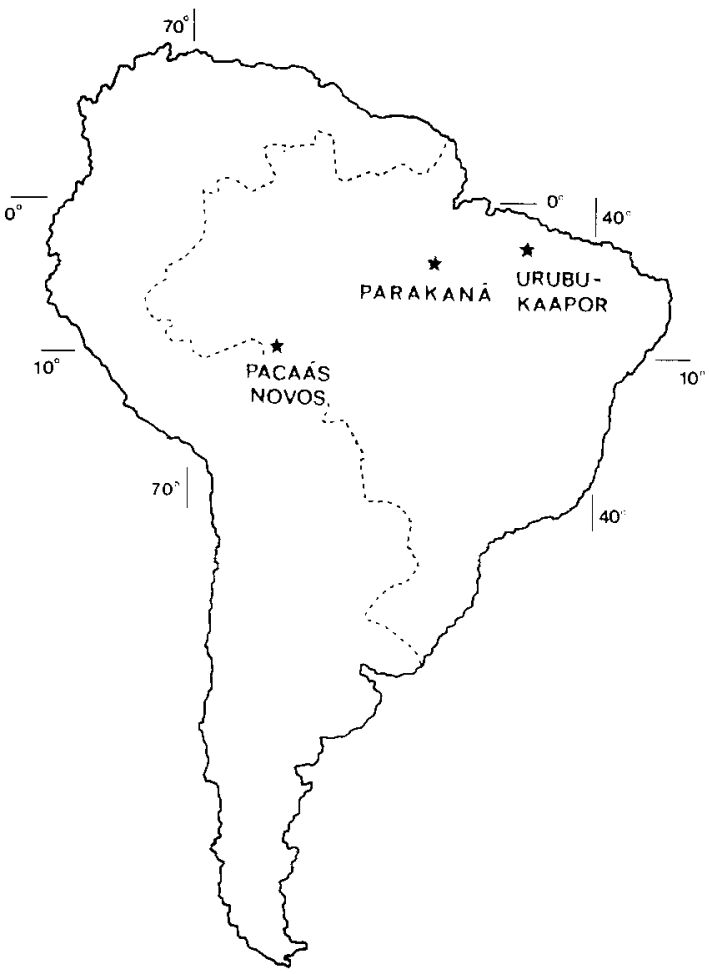

Fig. 1. South America's map showing where the studied populations live.

(1985).

The ORM typing was carried out by polyacrylamide gel isoelectric focusing (IEF) followed by immunoprinting (Yuasa et al., 1986; Umetsu et al., 1989a). The AHSG typing was determined by polyacrylamide gel IEF followed by immunoblotting (Yuasa and Umetsu, 1988). The IF typing was carried out by agarose IEF followed by immunoblotting (Ding et al., in press).

\section{RESULTS}

Table 1 presents the phenotype prevalences, and Table 2 the allele frequencies for the four loci studies. There is little intratribal differentiation among the Pacaás Novos, and the results concerning them will be examined considering the tribe as a whole.

In the ORM1 locus only two alleles were observed among the Urubu-Kaapor, but as many as five including two duplicated alleles $(O R M 1 * 2 \cdot 1$ and $O R M 1 * 5 \cdot 2)$ among the Pacaás Novos. The frequency of $O R M I^{*} 1$ among these two tribes was similar to each other ( 0.734 and 0.715 , respectively), but differed markedly from 
Table 1. Phenotype prevalences considering four loci investigated in three Brazilian Indian tribes.

\begin{tabular}{|c|c|c|c|c|c|c|}
\hline \multirow{2}{*}{ Phenotypes } & \multirow{2}{*}{ pes } & \multicolumn{2}{|l|}{ - } & \multicolumn{3}{|c|}{ Pacaás Novos } \\
\hline & & Urubu-Kaapor & Parakanã & Tanajura & Santo André & Total \\
\hline \multirow[t]{9}{*}{ ORM1 } & 1 & 41 & 88 & $44 a$ & 55 & 99 \\
\hline & 2.10 & 31 & 17 & 27 & 38 & 69 \\
\hline & 2 & 5 & 1 & 2 & 6 & 8 \\
\hline & $2 \cdot 1-1$ & 0 & 9 & 1 & 2 & 3 \\
\hline & $2 \cdot 1-2$ & 0 & 1 & 0 & 0 & 0 \\
\hline & $5=1$ & 0 & 0 & 2 & 0 & 2 \\
\hline & $5-2 c$ & 0 & 0 & 0 & 2 & 2 \\
\hline & $5 \cdot 2-1$ & 0 & 0 & 10 & 8 & 18 \\
\hline & $5 \cdot 2 \cdot 2$ & 0 & 0 & 2 & 1 & 3 \\
\hline \multirow[t]{2}{*}{ ORM2 } & 1 & 77 & 116 & 85 & 112 & 197 \\
\hline & $3-1$ & 0 & 0 & $3^{a}$ & 0 & 3 \\
\hline \multirow[t]{4}{*}{ AHSG } & 1 & 11 & 35 & 3 & 6 & 9 \\
\hline & $2=1$ & 37 & 55 & 19 & 21 & 40 \\
\hline & 2 & 29 & 26 & 63 & 85 & 148 \\
\hline & $\mathrm{PN}-2$ & 0 & 0 & 3 & 0 & 3 \\
\hline \multirow[t]{2}{*}{ IF } & B & 59 & 116 & 88 & 112 & 200 \\
\hline & A $3-B$ & 18 & 0 & 0 & 0 & 0 \\
\hline
\end{tabular}

a The three samples had the $O R M 1 * I-O R M 2 * 3$ haplotype. b Including two ORM1 (2/1 and $2 \cdot 1 / 2 \cdot 1)$ genotypes. Including two ORM1 $(5 / 2$ and $5 \cdot 2 / 5 \cdot 2)$ genotypes.

Table 2. Allele frequencies in four loci of three Brazilian Indian tribes.

\begin{tabular}{|c|c|c|c|c|c|}
\hline \multirow{2}{*}{ Alleles } & \multirow{2}{*}{ Urubu-Kaapor } & \multirow{2}{*}{ Parakanã } & \multicolumn{3}{|c|}{ Pacaás Novos } \\
\hline & & & Tanajura & Santo André & Total \\
\hline$O R M I * I$ & 0.734 & 0.870 & 0.727 & 0.705 & 0.715 \\
\hline$O R M I^{* 2}$ & 0.266 & 0.085 & 0.188 & 0.236 & 0.213 \\
\hline$O R M 1^{*} 2 \cdot 1$ & - & 0.045 & 0.006 & 0.009 & 0.007 \\
\hline$O R M I^{* 5}$ & - & - & 0.011 & 0.008 & 0.009 \\
\hline$O R M l^{*} 5 \cdot 2$ & - & - & 0.068 & 0.042 & 0.056 \\
\hline$O R M 2^{*} I$ & 1.000 & 1.000 & 0.983 & 1.000 & 0.992 \\
\hline$O R M 2^{*} 3$ & - & - & 0.017 & - & 0.008 \\
\hline$A H S G^{*} l$ & 0.383 & 0.539 & 0.142 & 0.147 & 0.145 \\
\hline$A H S G^{*} 2$ & 0.617 & 0.461 & 0.841 & 0.853 & 0.847 \\
\hline$A H S G^{*} P N$ & - & - & 0.017 & - & 0.008 \\
\hline$I F^{*} B$ & 0.883 & 1.000 & 1.000 & 1.000 & 1.000 \\
\hline$I F^{*} A 3$ & 0.117 & - & - & - & - \\
\hline
\end{tabular}


the data in the Parakanã (0.870). Variation for ORM2 was found among the Pacaás Novos only, with $O R M 2 * 3$ being observed in just three among 200 individuals.

As for the common alleles in the AHSG system, the Pacaás Novos show an extremely low frequency of $A H S G^{*} I(0.145)$, the prevalences among the UrubuKaapor and Parakanã being 0.383 and 0.539 , respectively, also quite low. As shown in Fig. 2, a new AHSG variant was observed in the Pacaás Novos population. The variant in the native state was indistinguishable from AHSG 16 and in the desialylated state was indistinguishable from AHSG 2. The AHSG 16 was located between AHSG 1 and AHSG 2 (Fukuma et al., 1990). A family data was available to show a codominant inheritance (Fig. 4).

For IF, variability again was restricted to just one tribe (Urubu-Kaapor),

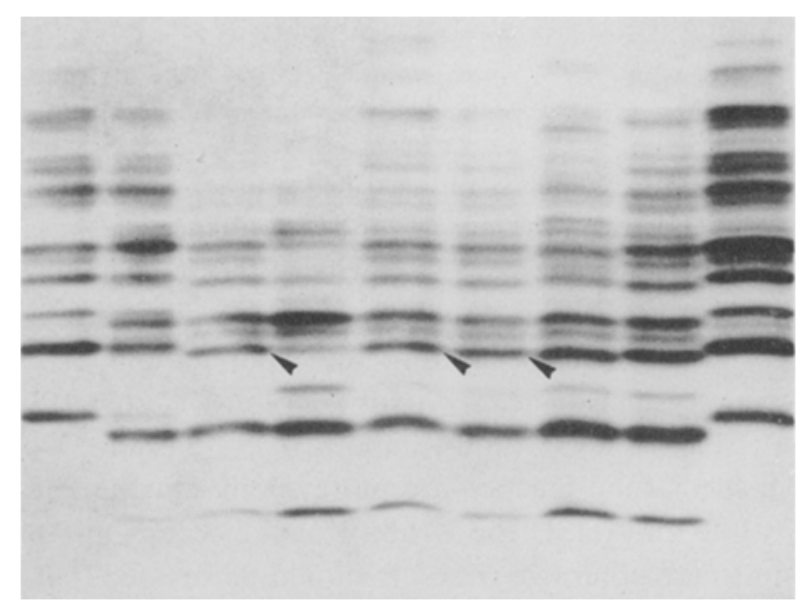

Fig. 2. Immunoblotted patterns of AHSG after IEF of native samples. Anode is at the top. Phenotypes from left to right: AHSG 1, 2-1, PN-2 (mother), 2 (father), PN-2 (twin), PN-2 (twin), 8-2 (control), 16-2 (control) and 1. Filled triangles indicate major variant bands.

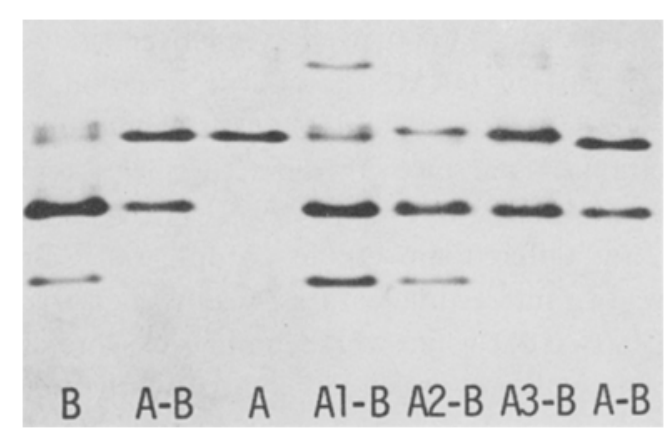

Fig. 3. Immunoblotted patterns of IF phenotypes. Anode is at the top. 

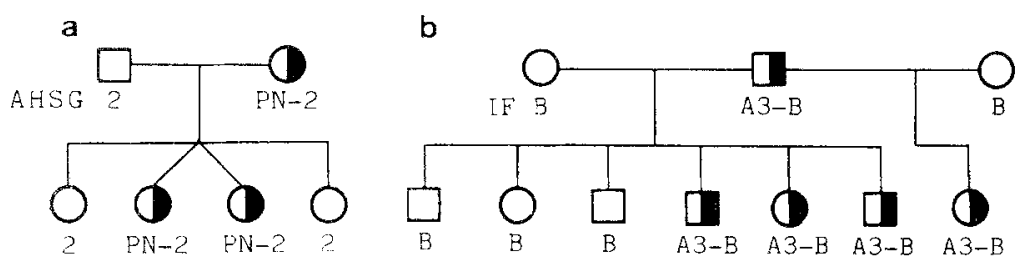

Fig. 4. Pedigrees of families with AHSG PN (a) and IF A3 (b). The twins who are carriers of the AHSG PN variant are identical in 32 genetic systems (probability of dizygosis, less than one in 1,000 ).

but in this case the new allele found $\left(I F^{*} A 3\right)$ occurs in polymorphic frequencies. The new variant band migrated between IF A and IF A2 (Fig. 3). Pedigrees demonstrating the codominant inheritance of IF A3 are shown in Fig. 4.

\section{DISCUSSION}

How are the present results compared with other information available for these three tribes? The Urubu-Kaapor and Parakanã speak languages of the same stock and are closer geographically to each other than to the Pacaás Novos, who speak a very distinct language. These relationships, however, were not reflected in the genetic distances separating these populations, as calculated using 60 alleles of 20 genetic systems; Pacaás Novos--Urubu-Kaapor, 0.20; Pacaás Novos -Parakanã, 0.49; Parakanã-Urubu-Kaapor, 0.55 (Salzano et al., 1990). In the ORM1 system the Urubu-Kaapor are more similar to the Pacaás Novos than to the Parakanã, while for AHSG the Urubu-Kaapor occupy an almost equidistant position in relation to the other two tribes. It should be stressed that the Prakanã are unusually inbred, while the Urubu-Kaapor may have incorporated persons from other tribes.

The amount of information available on the world distribution of the alleles at the four loci varies markedly. Most of the data have been reviewed by Roychoudhury and Nei (1988), Yuasa and Umetsu (1988) and Umetsu et al. (1988, $1989 \mathrm{a}, \mathrm{b})$. Around 6,000 and 11,000 persons all over the world were tested for AHSG and ORM1, respectively. ORM2 shows little variation, but ORM2*6 presents prevalences around $4 \%$ in Japanese and Chinese (Umetsu et al., 1988). When variability occurs, the range is narrow with different alleles represented in different populations. Only few studies were done for IF (Yuasa et al., 1988). Variation at AHSG does not differentiate ethnic groups well. But the variability at the ORM1 locus shows two interesting features: (a) the high frequencies of $O R M I^{*} I$ in Asiatics (values of $0.68-0.81$ ) while whites and blacks present lower prevalences (many lower than 0.65) with not much differentiation between them; and (b) a clear north-south distinction in Asia, with lower frequencies of $O R M 1 * 1$ and higher of $O R M I^{*} 2 \cdot 1$ in the north. $O R M I^{*} 2 \cdot 1$, also, is present at low frequencies in 
two of the three Brazilian Indians.

The most marked features of the present results are: (a) the striking low frequencies of $A H S G^{*} 1(0.145-0.539)$, while previous results indicated a worldwide range of values between 0.56 and 0.84 ; and (b) the new polymorphism observed at the IF locus. Since $I F^{*} A 3$ is at present restricted to the Urubu-Kaapor, it can be provisionally labeled as a "private" polymorphism (Tanis et al., 1974, 1977). IF*A, which occurs with polymorphic frequencies in the various Mongoloid populations (Nakamura and Abe, 1985; Yuasa et al., 1988; Ding et al., in press), was not encountered in our present material.

Only the ORM loci have been previously studied among South American Indians. Escallon et al. (1987) reported no variation at the ORM2 locus and a frequency of 0.56 of $O R M I^{*} I$ among 62 Huitoto Indians of Colombia. This frequency is significantly lower than those observed in the three tribes, where the range in $0.715-0.870$ with an average of $0.77\left(\chi^{2}: 25.5 ; 1\right.$ d.f.; $\left.p<0.001\right)$. The observations in North American and Mexican Indians also indicate low prevalences of $O R M 1^{* 1}$ (Dogrib, $\mathrm{n}=169: 0.55$, Escallon et al., 1987; Mexican $\mathrm{n}=24,0.54$, Johnson et al., 1969; Mayan, $\mathrm{n}=62$, 0.62; Escallon, 1987). The comparison of the findings between North and South American Indians, however, is difficult because of differences in methodology; for instance, among North American Indians

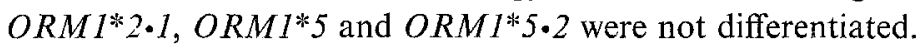

As for the AHSG system, two admixed populations with large amounts of Amerindian parentage have been studied. In both the frequency of $A H S G^{*} 1$ is that expected considering our values $(0.145-0.539)$ and the fact that non-Indian groups generally have higher prevalences of the gene (Mexican-Americans of Starr County, Texas, $\mathrm{n}=\mathbf{7 3 3}, 0.64$, Hewett-Emmett et al., 1986; Paraguayans from Asunción, $n=-200,0.56$, Umetsu et al., 1989b).

Acknowledgments We thank the Fundação Nacional de Indio (Funai) for permission to study the Indians and other assistance. Financial support of the National Institute of Health (USA), Conselho Nacional de Desenvolvimento Cienífico e Tecnológico and Financiadora de Estudos e Projectos (Brazil) are gratefully acknowledged. We also thank Dr. S. Nakamura (Tokyo) for the gift of the IF variant serum.

This work was supported in part by a Grant-in-Aid for Special Project Research (Prehistoric Mongoloid Dispersals) from the Ministry of Education, Science and Culture of Japan.

\section{REFERENCES}

Black, F.L., Salzano, F.M., Layrisse, Z., Franco, M.H.L.P., Harris, N.S. and Weimer, T.A. 1980. Restriction and persistence of polymorphisms of HLA and other blood genetic traits in the Parakanã Indians of Brazil. Am. J. Phys. Anthropol. 52: 119-132.

Black, F.L., Santos, S.E.B., Salzano, F.M., Callegari-Jacques, S.M., Weimer, T.A., Franco, M. H.L.P., Hutz, M.H., Rieger, T.T., Kubo, R.R., Mestriner, M.A. and Pandey, J.P. 1988. Genetic variation within the Tupi linguistic group: new data on three Amazonian tribes. Ann. Hum. Biol. 15: 337-351.

Ding, M., Umetsu, K., Yuasa, I., Nakamura, S., Choi, W. and Suzuki, T. Distribution of com- 
plement component $I$ types among three Mongoloid populations. Hum. Hered. in press.

Escallon, M.H. 1987. Genetic studies of the human $\alpha_{1}$-acid glycoprotein (orosomucoid). Ph.D thesis, University of Texas, Houston, USA.

Escallon, M.H., Ferrel, R.E. and Kamboh, M.I. 1987. Genetic studies of low-abundance human plasma proteins. V. Evidence for a second orosomucoid structural locus (ORM2) expressed in plasma. Am. J. Hum. Genet. 41:418-427.

Fukuma, Y., Kashimura, S., Umetsu, K., Yuasa, I. and Suzuki, T. 1990. Genetic variation of alpha-2-HS-glycoprotein in the Kyushu district of Japan: description of three new rare variants. Hum. Hered. 40: 49-51.

Hamel, M.L.H., Salzano, F.M. and Freitas, M.J.M. 1984. The Gm polymorphism and racial admixture in six Amazonian populations. J. Hum. Evol. 13: 517-529.

Hewett-Emmett, D., Hanis, C.L., Bertin, T.K., Chakraborty, R. and Schull, W.J. 1986. MexicanAmericans in Starr County, Texas: genetic markers, subtypes and disease. Am. J. Hum. Genet. 39 (suppl.): A237.

Johnson, A.M., Schmid, K., Alper, C.A. and Bisset, L. 1969. Inheritance of human $a_{1}$-acid glycoprotein (orosomucoid) variants. J. Clin. Invest. 48: 2293-2299.

Nakamura, S. and Abe, K. 1985. Genetic polymorphism of human factor I (C3b inactivator). Hum. Genet. $71: 45-48$.

Ricardo, C.A. 1986. Povos indígenas no Brasil--85/86. Centro Ecumênico de Documentação e Informação, São Paulo.

Roychoudhury, A.K. and Nei, M. 1988. Human Polymorphic Genes. World Distriburion. Oxford University Press, Oxford.

Salzano, F.M., Black, F.L., Callegari-Jacques, S.M., Santos, S.E.B., Weimer, T.A., Mestriner, M.A., Kubo, R.R., Pandey, J.P. and Hutz, M.H. 1990. Blood genetic systems in four Amazonian tribes. Am. J. Phys. Anthropol. in press.

Salzano, F.M., Weimer, T.A., Franco, M.H.L.P., Mestriner, M.A., Simões, A.L., Constans, J. and Freitas, M.J.M. 1985. Population structure and blood genetics of the Pacaás Novos Indians of Brazil. Ann. Hum. Biol. 12; 241-249.

Samain, E. 1984/85. A vontade de ser: notas sobre os índios Urubu-Kaapor e sua mitologia. Rev. Antrop. (São Paulo) 27/28: 245-262.

Tanis, R.J., Ferrel, R.E., Neel, J.V. and Morrow, M. 1974. Albumin Yanomama-2, a "private" polymorphism of serum albumin. Ann. Hum. Genet. 38: 179-190.

Tanis, E.J., Neel, J.V. and Arauz, R.T. 1977. Two more "private" polymorphisms of Amerindian tribes: $\mathrm{LDH}_{\mathrm{B} G U A-1}$ and $\mathrm{ACP}_{1} \mathrm{BGUA}-1$ in the Guaymi in Panamá. Am. J. Hum. Genet. 29: 419-430.

Umetsu, K., Yuasa, I., Chen, E.-G., Kudo, T. and Suzuki, T. 1988. Orosomucoid 1 and orosomucoid 2 types in the Taiwanese and Japanese: Evidence for five new orosomucoid variants. Electrophoresis 9: 224-226.

Umetsu, K., Yuasa, I., Nishi, K., Brinkman, B. and Suzuki, T. 1989a. Orosomucoid (ORM) typing by isoelectric focusing: description of two new alleles in a German population and thermostability in bloodstains. Z. Rechtsmed. 102: 171-177.

Umetsu, K., Yuasa, I., Yamashita, T., Saito, S., Yamaguchi, T., Ellepola, S.B., Ishida, T. and Suzuki, T. 1989b. Genetic polymorphisms of orosomucoid and alpha-2-HS-glycoprotein in Thai, Sri Lankan and Paraguayan populations. $J_{p n}$. J. Human Genet. 34: 195-202.

Yuasa, I., Umetsu, K., Suenaga, K., Ito, K., Iha, M., Hirata, H., Robinet-Lévy, M., Inoue, T. and Okada, K. 1988. Factor I (C3b inactivator) polymorphism among five populations in Eurasia. Hum. Hered. 38: 91-94.

Yuasa, I., Umetsu, K., Suenaga, K. and Robinet-Lévy, M. 1986. Orosomucoid (ORM) typing by isoelectric focusing: Evidence for two structural loci ORM1 and OEM2. Hum. Genet. 74: $160-161$.

Yuasa, I. and Umetsu, K. 1988. Genetic polymorphism of human $\alpha_{2}$ HS-glycoprotein: characterization and application to forensic hemogenetics. Electrophoresis 9: 404-410. 